Ivanenko Tetiana, Candidate of Economic Sciences, Associate Professor of the Department of Hotel and Restaurant Business and Business Organization, Mykolayiv National Agrarian University

ORCID ID: 0000-0003-0518-2563

e-mail: ivanenkoty@mnau.edu.ua

Porudeyeva Tatyana, Candidate of Economic Sciences, Researcher of the Mykolayiv State Agricultural Research Station of the Irrigated Institute of Agriculture of the National Academy of Agrarian Sciences of Ukraine e-mail: tanyapor@ukr.net

Andriushchenko Iana, Candidate of Pedagogical Sciences, Senior Lecturer of the Department of Hotel and Restaurant Business and Business Organization, Mykolayiv National Agrarian University

ORCID ID: 0000-0002-9191-7652

e-mail: andriushchenko@outlook.com

\title{
Assessment of Grain Production Development of the Black Sea Region of Ukraine
}

Abstract. Introduction. Grain products are among primary food resources and the most important source of income for agricultural producers, suitable for transportation and long-term storage, which makes it possible to form insurance and reserve funds; serves as the main source of raw materials for a number of branches of food and processing industries. Market reforms, which also affected the grain food subcomplex, provided all the conditions for its dynamic development. However, the grain farming in its development has increased the existing gap in comparison with the level of productivity of the grain industry in the countries - the largest producers of agricultural products. Currently, the grain economy of our country is characterized by an extremely extensive level of its management.

Purpose. The purpose of the study is to consider the theoretical foundations and develop practical recommendations to ensure the effective functioning of the grain industry of the Black Sea region in the context of grain farming.

Results. Analyzing the changes in the volume of gross regional product of the Black Sea region in the economy of Ukraine during 2013-2019, there is a tendency to active development of the Black Sea region of Ukraine. According to the grouping of agricultural producers of the Black Sea region, due to the average production costs per 1 ha of grain crops, it is proved that in almost every eighth enterprise in the region the increase in gross production is not repaid by increasing costs per 1 ha. The analysis of total imports and exports of grain products of the Black Sea region shows that the total exports of all types of grain and grain products are declining and there is a tendency to increase imports of this crop.

Conclusions. It is proved that the main condition for the effective functioning of the grain industry is the introduction of resource- and energy-saving technologies that will save material costs, increase yields while improving soil fertility. The issue of improving the infrastructure of the grain market remains important, which will minimize the number of available intermediaries during the implementation, which will ultimately have a positive impact on the final results of economic activity of grain producers in the Black Sea region.

Keywords: grain production; Black Sea region; production; market; profitability; efficiency; market infrastructure.

\section{УДК 338: (477.7)}

Іваненко Т. Я., кандидат економічних наук, доцент кафедри готельно-ресторанної справи та організації бізнесу, Миколаївський національний аграрний університет, м. Миколаїв, Україна

Порудєєва Т. В., кандидат економічних наук, провідний науковий співробітник, Миколаївська державна сільськогосподарська дослідна станція Інституту зрошуваного землеробства Національної академії аграрних наук України

Андрющенко Я. Е., кандидат педагогічних наук, старший викладач кафедри готельно-ресторанної справи та організації бізнесу, Миколаївський національний аграрний університет, м. Миколаїв, Україна

\section{Оцінка розвитку зерновиробництва Причорноморського регіону України}

Анотація. У статті розглянуто та проаналізовано тенденції розвитку зернової галузі Причорноморського регіону України. Сільськогосподарські товаровиробники Причорноморського регіону, до якого увійшли підприємства Миколаївської, Одеської та Херсонської областей, мають у розпорядженні потенційні можливості для забезпечення економічного функціонування галузі. Проаналізовано динаміку ефективності виробництва зернової продукції сільськогосподарськими товаровиробниками регіону. Зернове господарство Причорномор'я активно розвивається, спостерігається загальне зростання валового регіонального продукту впродовж останніх трьох років.

За групуванням сільськогосподарських товаровиробників Причорноморського регіону за середніми даними виробничих витрат на 1 га посівів зернових доведено, що майже в кожному восьмому підприємстві регіону приріст валового виробництва не окупається підвищенням рівня витрат на 1 га. Аналіз загального імпорту та експорту 
продукції зернової галузі Причорноморського регіону свідчить, що загальний обсяг експорту всіх видів зерна $i$ зернопродуктів скорочуватися, існує тенденція до підвищення імпорту цієї важливої в господарської діяльності культури.

Доведено, що головною умовою ефективного функціонування галузі зерновиробництва $\epsilon$ впровадження ресурсо- та енергозберігаючих технологій, які сприятимуть економії матеріальних витрат, підвищенню врожайності при одночасному поліпшенні родючості грунту. Важливим залишається питання покращення інфраструктури ринку зерна, що дозволить мінімізувати кількість наявних посередників під час реалізації, що в кінцевому рахунку позитивно вплине на кінцеві результати господарської діяльності товаровиробників зернової продукції Причорноморського регіону.

Ключові слова: зерновиробництво; Причорноморський регіон; виробнищтво; ринок; рентабельність; ефективність; ринкова інфраструктура.

Problem statement. The level of development of grain farming in Ukraine traditionally determines the solution of the country's food supply. Grain, due to its properties and characteristics, is crucial in the formation of food resources, is an economically, socially and politically significant product. The priority of grain in food resources is due to its objective advantages over all other crops: it has high nutritional and feed advantages, which determines the high share of bread and cereals in the diet and feed resources of livestock; it is the most important source of income for agricultural producers; it is well transported, suitable for long-term storage, which allows farmers to form insurance and reserve funds; it serves as the main source of raw materials for a number of branches of food and processing industries.

This necessitates its production in almost all regions of the country, taking into account soil and climatic conditions and biological characteristics of production. Market reforms, which also affected the grain food subcomplex, provided all the conditions for its dynamic development. However, the grain economy in its development has increased the existing gap in comparison with the level of productivity of the grain industry in the countries - the largest producers of agricultural products. Currently, the grain production of our country is characterized by an extremely extensive level of its management, which fully extends to the grain market.

Analysis of recent research and publications. It should be noted that the works of such scientists as S. Gannachenko [1], S. Kvasha, M. Ilchuk, I. Konoval [2], P. Sabluk [3] and others are devoted to the problems of formation of balanced agricultural markets. In addition, the issues of theory and practice of formation of cooperative-integration structures in the grain subcomplex are reflected in the works of Yu. Lupenko, A. Gutorov [4,5]. Mesel-Veselyak V. [6], Yu. Kernasyuk [7], O. Bodnar [8] and others. In their works the issues of formation and regulation of the grain market, creation of an effective system of sales are analyzed.

Increasing the level of sustainability of the regional grain market largely depends on the organizational and economic relations of its subjects in the processes of production, transportation, storage and sale of finished products.

The urgency of solving these issues, as well as the importance of scientific justification of the organizational and economic mechanism of formation and effective functioning of the regional grain market at the present stage of development have determined the direction of the study.

Formulation of research objectives. The purpose of the study is to consider the theoretical foundations and develop practical recommendations to ensure the effective functioning of the grain industry of the Black Sea region in the context of grain farming.

Presentation of the main research material. Ensuring food security of the state depends primarily on the development of its grain industry, because its socioeconomic significance, as well as the size of the involved logistical and financial resources, it is one of the most important in the agricultural sector of Ukraine. In this regard, it is now necessary to address in a new way many organizational, economic, technological and technical issues of grain farming. At the same time, all of them, on the one hand, should be aimed at significantly increasing grain production through the use of the potential of the industry and the optimal combination of intensive and extensive factors, and on the other - to ensure its rational use. In addition, the grain industry, being one of the most important structural parts of the agro-industrial complex, is designed to meet the needs of the region in food and feed grain, to form the necessary seed funds, insurance and state reserves, which allow uninterrupted supply of bread. from fluctuations and seasonality of production. The successful solution of these problems depends on the dynamic proportional development of all its subsectors, which must be united by the sole purpose of effective and maximum production of the final product of the required range and quality.

Studies have shown that the regional features of the grain market are due to natural and climatic conditions, its specialization, available economic potential, environmental and other characteristics.

The southern region of Ukraine now unites Odesa, Mykolayiv and Kherson regions within the Black Sea economic region.

The grain industry has always occupied a leading place in the structure of the agro-industrial complex of the Black Sea region due to favorable natural and climatic conditions, soil fertility and historical experience of farmers, which ultimately ensured efficient grain production. The studied region has a number of features: it has, first of all, favorable natural and climatic conditions that allow to grow food grain. Secondly, the technologies developed over the centuries, the presence of large arrays of chornozems allow farmers to grow grain with a 
relatively low production cost. Third, the availability of sales infrastructure and proximity to seaports can provide the lowest costs of the marketing chain. In general, these factors should have a positive impact on the region's competitiveness in world markets, fully meeting its own needs for grain products.

At the regional level, the indicator that characterizes the overall level of economic development of the region is the gross regional product (GRP). The importance of GRP in the management of the region is that it is an indicator of economic growth, efficiency of the region's potential and resources involved (Fig. 1).

Analyzing the change in the volume of gross regional product of the Black Sea region in the economy of Ukraine during 2013-2019, we observe the overall growth of gross regional product throughout the study period, so the Black Sea region is actively developing.

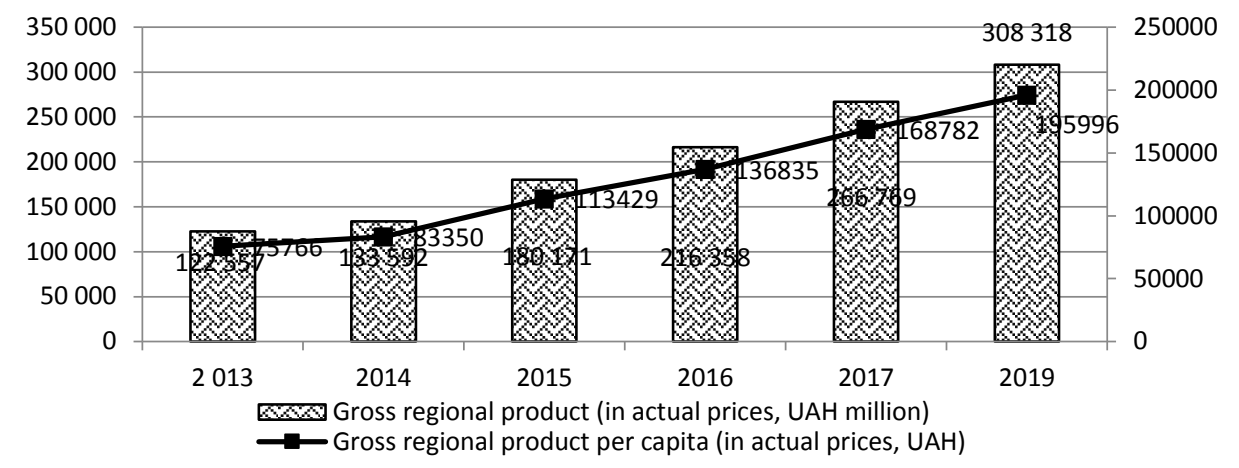

Figure 1 - Dynamics of gross regional product of the Black Sea region for 2013-2019, UAH million [9]

In order to assess the state and sustainability of the studied industry of the Black Sea region more objectively, we considered the indicators of grain production for 20172019 (Fig. 2).
Analysis of indicators of grain production on average for $2017-2019$ shows that $62.5 \%$ of total production is wheat. During the analyzed period, there is a tendency to reduce the yield of the main grain crop by 3.3 quintals per $1 \mathrm{ha}$. One in five tons of gross grain production is barley.

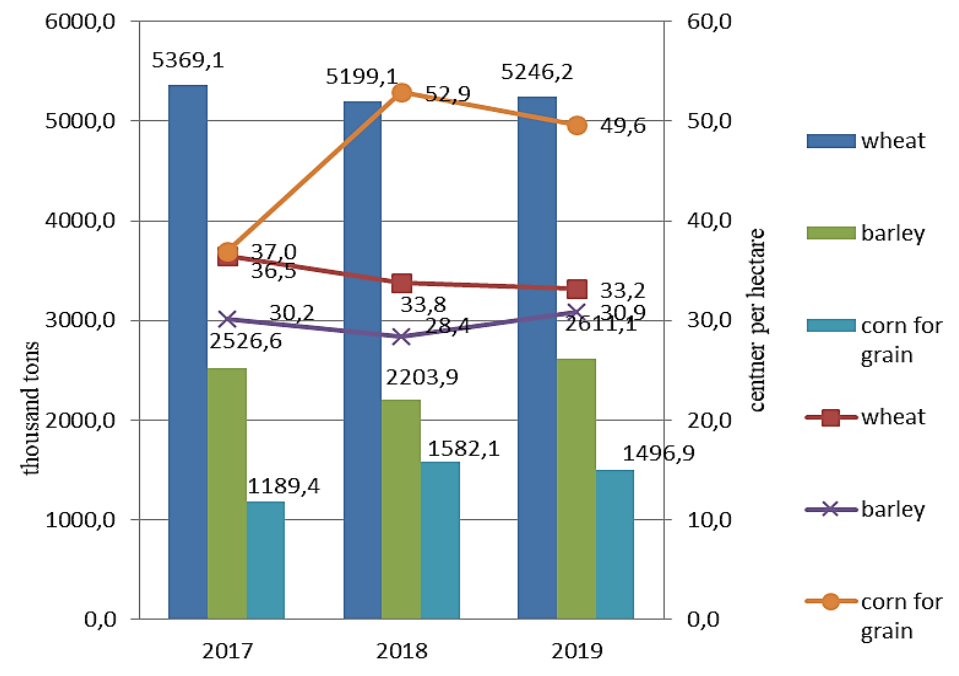

Figure 2 - Indicators of grain production for 2017-2019

It should be noted that in the Black Sea region the consistently high rate of grain production was only for barley - 2611.1 thousand tons, the production of other cereals in 2019 decreased significantly.

In recent years, there has been a positive trend of annual increase in gross grain harvest due to an increase in sown areas. The first place in the Black Sea region both in terms of sown areas -1581.2 thousand hectares, and in terms of production is wheat (Fig. 3).

High grain yields are the most important condition for improving the efficiency of grain production. But since
2017, there has been a gradual decrease in wheat yields, and as a result of gross harvests. In 2019, with a rate of 33.2 quintals/ha, 5,446.2 thousand tons of grain were received.

The next crop of grain wedge in 2019, both in terms of sown area over 845.2 thousand hectares and in terms of gross harvest of 2611.1 thousand tons, is winter and spring barley. Over the last 3 years, there have been fluctuations in yield from 30.2 quintals / ha in 2017 to 28.4 quintals / ha in 2018 and 30.9 quintals / ha in 2019. 


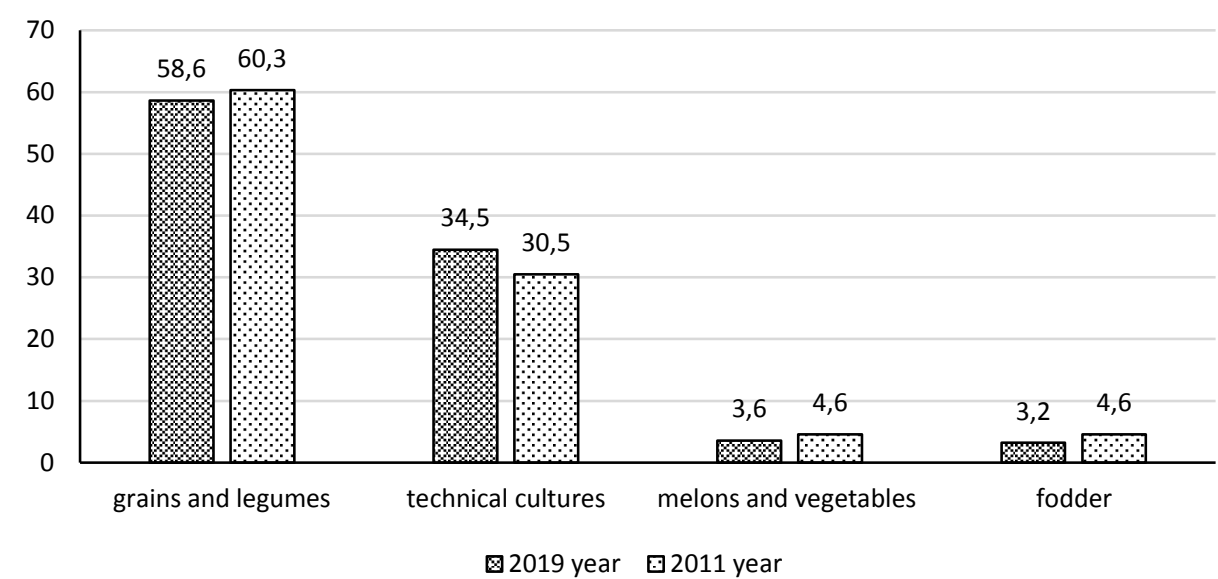

Figure 3 - The share of sown areas of cereals in the Black Sea region, \% [9]

Corn for grain is the third leader of a grain wedge. Its production volume for the last 3 years ranged from 1189.4 thousand tons in 2017 to 1496.9 thousand tons. However, in 2018 the production of corn for grain due to the yield of $52.9 \mathrm{~kg} / \mathrm{ha}$ gave the largest gross collection at the level of 1582.1 thousand tons.

Thus, the study shows that the intensity of development of the grain industry characterizes the yield of cereals and legumes. It depends on the influence of natural conditions, as features of agricultural production.
This primarily refers to the natural fertility of the soil. Since cereals and legumes in the enterprises of the Black Sea region occupy $58.6 \%$, they are placed on almost all types of soils and without compliance with scientifically sound standards (crop rotation). This leads to inefficient grain production.

Lower economic efficiency of production and sale of grain crops of farms in the Black Sea region compared to the average in Ukraine shows a lower technological level of development of the industry (Fig. 4).

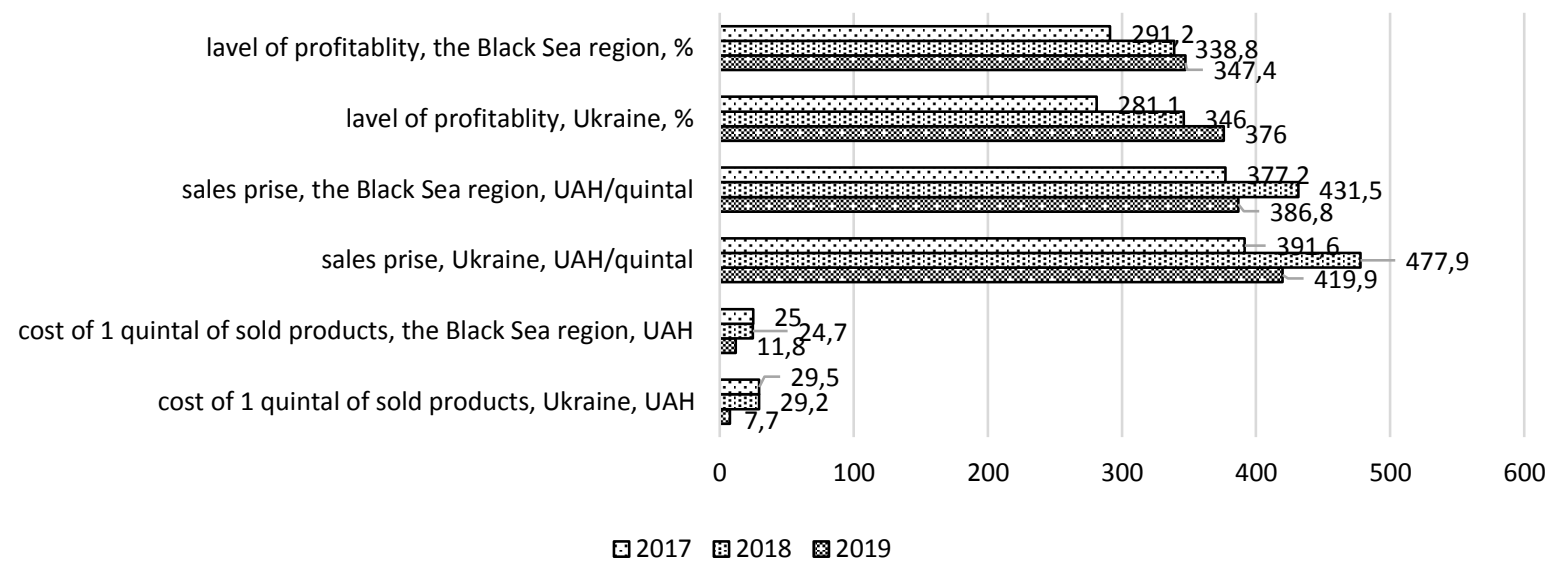

Figure 4 - Dynamics of economic efficiency of grain production in agricultural enterprises of the Black Sea region in 2017-2019 [9]

Indicators of economic efficiency of grain production in the Black Sea region in comparison with Ukraine for the period 2017-2019 were the highest in 2017 when the level of profitability was $29.5 \%$.

Indicators of economic efficiency of grain production in the Black Sea region and in comparison with Ukraine as a whole for the period 2017-2019 were the highest in 2017 when the level of profitability was $29.5 \%$.

Today, the issue of intensification of production remains significant, which is based on the introduction of innovations that can increase labor productivity, help reduce material costs. Advancing financial resources for grain production should provide an increase in grain production while reducing the cost of its production and sale.

The grouping of agricultural producers in the Black Sea region according to the average data of production costs per 1 ha of grain crops for 2017-2019 (Table 1) allows us to conclude that enterprises that spent more than 11,000 $\mathrm{UAH}$ received the highest yields, but the profitability of its production is inferior to agricultural enterprises that spent on 1 hectare up to UAH 5,500 - by 16.4 percentage points. and 9.7 percentage points, which spent up to UAH 11,000.

This indicates that the increase in gross production is not payed off by increasing costs per 1 ha. In addition, the main condition for the effective functioning of the grain 
industry is the introduction of resource- and energysaving technologies that will save material costs, increase yields while improving soil fertility.

Table 1 Grouping of agricultural producers of the Black Sea region by production costs per 1 ha of crops on average for 2017-2019

\begin{tabular}{|l|c|c|c|c|c|}
\hline \multirow{2}{*}{ Indicators } & \multicolumn{2}{|c|}{$\begin{array}{c}\text { Groups of enterprises by production costs per } 1 \text { ha of } \\
\text { sowing, UAH }\end{array}$} & \multirow{2}{*}{ Total } \\
\cline { 2 - 5 } & $\begin{array}{c}\text { III- from } \\
\text { to } 5500\end{array}$ & $\begin{array}{c}\text { II -from } \\
5500 \\
\text { to11000 }\end{array}$ & $\begin{array}{c}\text { 11001 to } \\
16500\end{array}$ & $\begin{array}{c}\text { IV - } \\
\text { over16500 }\end{array}$ & \\
\hline Number of enterprises & 361 & 834 & 152 & 25 & \\
\hline Total area, thousand hectares & 703 & 1758 & 552 & 205 & 2808,3 \\
\hline Yield, c from 1 ha & 19,7 & 29,5 & 37,1 & 43,7 & 33,7 \\
\hline Profit, UAH million & 594,42 & 2934,39 & 689,58 & $-32,29$ & 4186,1 \\
\hline The cost of 1 quintal of sold grain, UAH & 276,53 & 323,22 & 380,69 & 442,18 & 334,33 \\
\hline Sales price 1 quintal, UAH & 358,94 & 397,84 & 432,23 & 426,03 & 402,00 \\
\hline Profit (+), loss (-) from sales of 1 quintal, UAH & 82,41 & 74,62 & 51,54 & $-16,15$ & 67,67 \\
\hline Profitability (+), loss (-), \% & 29,8 & 23,1 & 13,4 & $-3,6$ & 20,0 \\
\hline
\end{tabular}

Research has shown that the country as a whole, including the Black Sea region, provides its own food security for such agricultural products as grain. However, it should be noted that the country produces mainly feed grain. This means that the country, including the Black Sea region, is forced to import certain types of cereals with high quality indicators for food purposes, as well as those species that are not grown in the country.

The analysis of total imports and exports of grain and grain products of the Black Sea region revealed a negative trend. The total export of all types of grain and grain products to the country since 2018 has been significantly reduced. Since 2017, there has been a tendency to increase imports by 10 million US dollars. This is largely due to falling yields and, consequently, to reduced gross harvests.

The grain market in addition to the supply of grain in the appropriate range and quantity also provides for all types of transactions for its implementation. The practical implementation of the process of buying and selling grain takes place with the help of appropriate market infrastructure. A small owner cannot provide quality storage due to lack of specific facilities. Therefore, grain in the south of Ukraine enters the market in the second half of the marketing season, and has a significantly lower quality. Therefore, both in Ukraine as a whole and in the Black Sea region, it is necessary to provide a sufficient number of properly equipped warehouses, as well as a special database on the availability and accounting of grain of homogeneous quality.

The TOP-5 shippers of Ukrainian grain in 2019/20 MY included:

1. Kernel -7.98 million tons of grain (1.9 million tons more than in 2018/19 MY), with a market share of $13.29 \%$;

2. COFCO Agri Ukraine - 5.03 million tons $(+410$ thousand tons), $8.37 \%$;

3. NIBULON -4.98 million tons ( -139 thousand tons), 8.28\%;
4. "Cargill" - 4.39 million tons (+805 thousand tons), 7.31\%;

5. Louis Dreyfus Company Ukraine -4.13 million tons (+978 thousand tons), $6.87 \%$.

The largest shipper of grain in 2019/20 MY was the company "Kernel" with a market share of $13.29 \%$. At the same time, the company increased shipments by 1.9 million tons during the year. The company also operated through "TIS" and "Nika-Terra" terminals. The destinations for which the largest amount of grain was shipped by Kernel: China (1.64 million tons), the Netherlands (1.3 million tons), Indonesia ( 0.75 million tons), Egypt (0.63 million tons).

Analyzing the state of the grain economy of the Black Sea region in terms of its effective formation, it is necessary to name the factors that constrain the growth of grain production, as well as to propose a list of measures to identify new opportunities for grain producers in the Black Sea region. To form a high grain yield, it is necessary to develop a system of fertilizer application taking into account the latest advances in science and best practices and to ensure appropriate optimal plant nutrition conditions. At the same time, first of all, it is necessary to provide a sufficient supply of organic fertilizers, as in recent years in most agricultural organizations there is a lack of financial resources for the purchase of mineral fertilizers. Adherence to the system of crop rotations, as well as the use of zoned and promising varieties are of great importance in increasing the gross grain harvest and increasing its yield. Their potential is demonstrated by the constant requirements of intensive technology and a fairly high level of seed production, as crop rotations significantly improve the agronomic properties of the soil, help control weeds, prevent the spread of various pests and diseases, and provide quality growth of soil fertility and contribute to increasing the yield of all crops. Optimization of crop rotations taking into account the characteristics of each field and suitability for certain crops will offer a rational 
structure of sown areas and, accordingly, increase the yield of cereals and legumes.

Conclusions from the study. The functioning of the grain industry of the Black Sea region is characterized by an appropriate level of sustainability, which should be considered as one of the many characteristics of the dynamics of grain farming. Its indicators simultaneously reflect the degree of reliability and efficiency of economic activity, as well as allow to take the totality of factors influencing the final results of the industry into account. Under such stability should be understood not only the ability to overcome adverse weather conditions, but also the ability to use them to achieve maximum effect, as well as continuously maintain a certain proportionality of grain production and consumption.
The main tasks of further development of grain production of the Black Sea region are: development of advanced technologies of grain growing; creation of necessary conditions for commodity producers, including improvement of credit-financial, price and tax policy; formation of the mechanism of economic development of the region taking into account the requirements of the market; elimination of a large number of intermediaries and the organization of direct links between producers and markets for their products.

In the future, the tasks of the country's grain production development are determined by the need for its self-sufficiency in grain in terms of volume, range and quality, as well as the transition to a balaned export and import.

\section{References:}

1. Hannachenko, S. L. (2010). The world agri-food market at the present stage of development: prospects for Ukraine. Ekonomika $i$ prohnozuvannia, 1, 142-153 [in Ukrainian].

2. Kvasha, S. M., Ilchuk, M. M. \& Konoval, I. A. (2013). Economic feasibility of the production of wheat in Ukraine. Ekonomika APK, 3, 1624 [in Ukrainian].

3. Sabluk, P. T. (2014). Ekonomichnyi interes u rozvytku ahrarnoho vyrobnytstva. Kyiv: NNTs «IAE».

4. Lupenko, Yu. O. \& Hutorov, A. O. (2016). Vyrobnycha typizatsiia silskohospodarskykh tovarovyrobnykiv Ukrainy. Kharkiv: TOV "Smuhasta typohrafiia».

5. Hutorov, A. O. (2016). Rozvytok intehratsiinykh vidnosyn v ahrarnomu sektori ekonomiky. Kyiv: TOV «SIK HRUP UKRAINA».

6. Mesel-Veseliak, V. Ya. (2018). Cereal production in Ukraine: potential opportunities. Ekonomika APK, 5, 5-14 [in Ukrainian].

7. Kernasyuk, Yu. (2018). World grain market: supply and demand. Ahrobiznes S'ohodni, 1/2, 12-16 [in Ukrainian].

8. Shpychak, O. M. \& Bodnar, O. V. (2014). Optimization of the grain market of Ukraine and its effectiveness. Monitorynh birzhovoho rynku, 2(21), 8-14 [in Ukrainian].

9. Official site of the State Statistics Service (2020). Retrieved from http://ukrstat.gov.ua/ [in Ukrainian]. 